\title{
Effect of Eucalyptus Based Agri-Silvi-Horticultural System on Growth and Yield of Wheat in North-Western Region of Haryana, India
}

\author{
Vishal Johar", R.S. Dhillon, K.S. Bangarwa and K.K. Bhardwaj \\ Department of Forestry, CCS Haryana Agricultural University, Hisar-125 004, Haryana, India \\ *Corresponding author
}

\begin{abstract}
Keywords
Wheat, Eucalypts, Kinnow, Agroforestry and India.

Article Info

Accepted:

20 September 2017

Available Online:

10 November 2017 Kinnow-Wheat) on production potential of wheat. The experiment was laid out following split-plot design with three replications. Wheat variety HD-2967 was sown to test its performance under pre-established five years old plantation of Kinnow alone and Kinnow +Eucalypts in comparison to control (devoid of trees). The data revealed that the significantly higher grain and straw yield of wheat (2.79 and $4.15 \mathrm{t} /$ ha respectively,) was observed in case of agri-horti (kinnow + wheat) system as compared to agri-silvi-horti system (1.46 t/ha and $2.26 \mathrm{t} / \mathrm{ha}$ respectively) when $20 \%$ extra dose of nitrogenous fertilizer was added as compared to the recommended dose. Further, it was also observed that the agroforestry system tremendously affected the soil physical and chemical properties. It was observed that the soil organic carbon and electrical conductivity were significantly affected while there was no effect on soil $\mathrm{pH}$. Similarly, soil nutrient status was also significantly affected show a significant decrease in $\mathrm{N}$ and $\mathrm{K}$ concentrations after the harvest of the wheat crop.
\end{abstract}

\author{
A B S T R A C T
}

The study was conducted during 2015-16 at the research farm of CCS Haryana Agricultural University, Hisar, India to assess the effect of three-tier system (Eucalypts-

\section{Introduction}

Haryana state with geographical area of 4.42 mha is predominantly an agrarian state having 80 percent of its area under intensive, technical and mechanical agriculture whereas forest occupy only $1586 \mathrm{~km}^{2}$, which comes out to be about 3.59 percent of total geographical area (Dhyan et al., 2013). In view of the prevailing socioeconomic and agroclimatic conditions favorable for agriculture in the state, it is also not possible to divert the fertile agriculture to forest. The only option to increase area under tree cover is to integrate the tree species with agricultural crop on farm lands. Traditional tree-integrated farming systems are adopted since time immemorial for security of food, fodder and fuel wood in drought-prone arid region (Harsh et al., 1992; Leakey and Simons, 1998; Ndayambaje and Mohren, 2011; FAO, 2013), but are unable to meet the requirement of the ever increasing population. There is a need of intensification of such treeintegrated system too to improve total land productivity as it provides greater carbon offset opportunities than any other climate mitigation practices in agriculture (FAO, 2004; Udawatta and Jose, 2012; Murthy et al., 2013). Agroforestry system is one of the options with multifunctional value among numerous issues involved with livelihood 
improvement in dry areas (Gathumbi et al., 2002; Pandey, 2007; Fukushima et al., 2010). The most important benefit of agroforestry systems is the enhancement in total production by improving soil fertility (Stahl $e t$ al., 2002; Singh, 2010), mitigation of soil carbon loss by erosion control, replenishment of nutrients removed through biomass harvest (Nair et al., 1999; Ilany et al., 2010), improvement in microbial population (Belsky et al., 1989; Yadav et al., 2008; Vallejo et al., 2012), economic benefits (Gajja et al., 1999; Jianbo, 2006; Fadl and Sheikh, 2010), and nutrient and water-use efficiency (Anderson et al., 2009; Pinho et al., 2011).

Belowground resources are more limiting than the above-ground resources in an arid environment that influences the growth and productivity of tree and crop both (Dalal et al., 2016). Productivity of the arid and semi arid region is about two times less as compared to humid and sub humid region therefore, enhancing income in the low rainfall region can be realized by cultivating different crops with fruit plants and forest trees in agri-silvi-horticultural system (Kumar et al., 2012). However, in most of the regions, people are reluctant to adopt agroforestry because of lesser short term benefits from silvicultural species.

Integrating horticultural species with silvicultural species will ensure income/productivity to the farmers much earlier. Irrigation to the system, where water is available, will provide added income to the farmers. While tree component in agri-silvihorticultural system maintains higher productivity, enhances economy of the farmers, improves farmers livelihood on sustainable basis and provides carbon sequestration benefits, wheat (Triticum aestivum) as staple food grown under irrigation (wherever water is available) could provide additional benefits of improved productivity of all components, i.e. tree, horticultural species and agriculture crop because of irrigation. Keeping in view the vital importance of agroforestry systems in present day context, the present study was planned to find out the effect of shade, multitier interaction and nutritional competition of both annual (Grain crop) and perennial (Kinnow plus Eucalypts) components of agri-silvi-horticultural system on production potential of various wheat varieties.

\section{Materials and Methods}

\section{Study sites and climate}

The present study was conducted during 2015-16 during winter season at CCS Haryana Agricultural University, Hisar $\left(29^{\circ} 09^{\prime} \mathrm{N}\right.$ latitude and $75^{\circ} 43^{\prime} \mathrm{E}$ longitude at an elevation of $215 \mathrm{~m}$ above sea level), situated in semi-arid region of North-Western India. The climate is subtropical-monsoonic with an average rainfall of $350-400 \mathrm{~mm}, 70-80$ per cent of which occurs during July to September. The summer months are very hot with maximum temperature ranging from 40 to $45^{\circ} \mathrm{C}$ in May and June whereas, December and January are the coldest months (lowest January temperature as low as $0^{\circ} \mathrm{C}$ ). The texture class of the soil is 'sandy loam' and the soil of the experiment site is medium in organic carbon, available $\mathrm{N}, \mathrm{P}$ and $\mathrm{K}$.

A pre-established five year old plantation of Kinnow alone and Kinnow plus Eucalypts was used as the basic agroforestry model in the study. The experiment was laid out in split plot design with three replications.

\section{Tree data and soil analysis}

The woody perennials at random were measured for their top height, girth at breast height $(\mathrm{GBH})$ and basal area. The top height 
was measured from ground to the top of the tree. The girth at breast height $(1.37 \mathrm{~m}$ above the ground level) was taken. For soil sampling, surface $(0-20 \mathrm{~cm})$ soil was sampled from five different spots from both the agroforestry systems and control. Soil samples were taken before the sowing of the wheat varieties in October and after harvesting of wheat varieties from both the agroforestry system and control for the study of various soil properties like $\mathrm{pH}, \mathrm{EC}$, organic carbon and available $\mathrm{N}, \mathrm{P}$ and $\mathrm{K}$. The samples were air dried, ground in wooden pestle with mortar, passed through a $2 \mathrm{~mm}$ stainless steel sieve and stored for subsequent analysis. The soil $\mathrm{pH}$ and electrical conductivity were determined in soil: distilled water suspension $(1: 2)$. The available $\mathrm{N}$ in soil was determined by alkaline permanganate method (Subbiah and Asija, 1956), organic carbon by Walkely and Black (1934) method, available $P$ by Olsen (1954) method and available K by neutral normal ammonium acetate method (Jackson, 1973).

\section{Wheat crop varieties}

Wheat variety HD-2967 representing early sown variety of north-western India was selected to test its performance under agrisilvi-horticultural system in comparison to control (devoid of trees). Four fertilizer levels i.e. recommended dose of fertilizer [RDF: 150 $\mathrm{kg} \mathrm{N}+60 \mathrm{~kg} \mathrm{P}_{2} \mathrm{O}_{5}+30 \mathrm{~kg} \mathrm{~K}_{2} \mathrm{O}+25 \mathrm{Kg}$ $\mathrm{ZnSO}_{4}$ per hactare), $\mathrm{RDF}+10 \%$ additional dose of $\mathrm{N}, \mathrm{RDF}+20 \%$ additional dose of $\mathrm{N}$ and $\mathrm{RDF}+30 \%$ additional dose of $\mathrm{N}$ were applied. Sowing of all the above varieties was done in the start of the second fortnight of November following all the package and practices. Observations for plant population, yield and yield attributing parameters such as plant height, number of tillers per plant, ear length, number of grains per ear, 1000-grain weight etc were recorded to assess the performance of variety under agri-silvi- horticultural system in comparison to control. The yield of the produce (grain and straw) was extrapolated to be expressed in $\mathrm{tha}^{-1}$ by bringing the produce at 14 per cent grain moisture content.

\section{Results and Discussion}

\section{Soil chemical properties}

Soil organic carbon and electrical conductivity were significantly affected by the perennial component, whereas the $\mathrm{pH}$ was non-significant. The electrical conductivity was lowered under both the agroforestry models. It was observed that the electrical conductivity of soil under agri-horticultural system reduced significantly after the harvest of the annual component then it was observed before sowing of wheat crop i.e. $0.28 \mathrm{~d} \delta \mathrm{m}^{-1}$ and $0.32 \mathrm{~d} \delta \mathrm{m}^{-1}$ respectively. Similar trend was also observed under agri-silvihorticultural system i.e. $0.34 \mathrm{~d} \delta \mathrm{m}^{-1}$ and 0.39 $\mathrm{d} \delta \mathrm{m}^{-1}$ respectively. A small amount of reduction was also observed for soil organic matter that may be due to lower decomposition rate of leaf litter during winter season as compared to the utilization by different components in a agroforestry system as compared to the sole cropping while no significant variation was observed for $\mathrm{pH}$ uner both the agroforestry system and sole crop as it takes a slightly longer duration to change soil $\mathrm{pH}$. Similar results were also reported by Gupta and Sharma (2009), Das and Chaturvedi (2005) and Yadav et al., (2008). Corroborative results were reported by Aguiar et al., (2010) with six month study on litter production under Poplar.

\section{Soil nutrient status}

Available soil nitrogen $(\mathrm{N})$ and potassium $(\mathrm{K})$, were significantly, whereas available phosphorus (P) was non-significantly influenced by the agroforestry systems as 
compared to the soil cropping (devoid of trees). The data in table 1 shows that the status of $\mathrm{N}$ under agri-horticultural system, agri-silvi-horticultural system and sole cropping were recorded to be $132 \mathrm{Kg} / \mathrm{ha}, 110$ $\mathrm{Kg} / \mathrm{ha}$ and $144 \mathrm{Kg} / \mathrm{ha}$ respectively, before sowing of the wheat crop which significantly reduced to $120 \mathrm{Kg} / \mathrm{ha}, 104 \mathrm{Kg} / \mathrm{ha}$ and 136 $\mathrm{Kg} / \mathrm{ha}$ respectively, under all the systems. Similar results were also observed for $\mathrm{K}$ which was earlier observed to be $320 \mathrm{Kg} / \mathrm{ha}$, $290 \mathrm{Kg} / \mathrm{ha}$ and $325 \mathrm{Kg} / \mathrm{ha}$ respectively, significantly reduced to $280 \mathrm{Kg} / \mathrm{ha}, 256 \mathrm{Kg} / \mathrm{ha}$ and $310 \mathrm{Kg} / \mathrm{ha}$ after harvest of the wheat this may be due to over utilization of the nutrients by the different components in the agroforestry system as returned to soil in the form of liter fall and its decomposition and also due to non-leguminous nature of all the components as a result of which there was no or a very less amount of atmospheric nitrogen fixation that further affect soil nutrient status. While, there was no significant difference in the concentration of $\mathrm{P}$ in soil before sowing and after harvesting of the wheat crop.

Nutrients are made available to plants in agroforestry mainly by atmospheric nitrogen fixation and mineralization of nutrients from organic forms (Muthuri et al., 2005; Fang et al., 2008; Jose, 2009; Hymavathi et al., 2010). The intercropping of trees with crops that are able to biologically fix nitrogen is common in tropical agroforestry systems. Non N-fixing trees can also affects soil physical, chemical and biological properties by adding some amount of organic matter and releasing and recycling of nutrients in agroforestry systems (Paoli et al., 2008; Yadav et al., 2008; Antonio and Gama-Rodrigues, 2011)

Table.1 Soil chemical properties of the experimental field before sowing and after harvest of wheat crop

\begin{tabular}{|c|c|c|c|c|c|c|c|c|c|c|c|c|}
\hline \multirow{3}{*}{ Treatment } & \multicolumn{6}{|c|}{ Before Sowing } & \multicolumn{6}{|c|}{ After Harvest } \\
\hline & \multirow{2}{*}{$\begin{array}{c}\text { pH } \\
(1: 2)\end{array}$} & \multirow{2}{*}{$\underset{\left(d \delta m^{-1}\right)}{E C}$} & \multirow{2}{*}{$\begin{array}{l}\text { OC } \\
(\%)\end{array}$} & \multicolumn{3}{|c|}{$\begin{array}{c}\text { Available Nutrients } \\
\left(\mathrm{Kg} \mathrm{ha}^{-1}\right)\end{array}$} & \multirow{2}{*}{$\begin{array}{c}\text { pH } \\
(1: 2)\end{array}$} & \multirow{2}{*}{$\begin{array}{c}E C \\
\left(\mathbf{d} \delta m^{-1}\right)\end{array}$} & \multirow{2}{*}{$\begin{array}{l}\mathrm{OC} \\
(\%)\end{array}$} & \multicolumn{3}{|c|}{$\begin{array}{l}\text { Available Nutrients } \\
\qquad\left(\mathrm{Kg} \mathrm{ha}^{-1}\right)\end{array}$} \\
\hline & & & & $\mathbf{N}$ & $\mathbf{P}$ & $\mathbf{K}$ & & & & $\mathbf{N}$ & $\mathbf{P}$ & $\mathbf{K}$ \\
\hline Kinnow + Wheat & 7.7 & 0.32 & 0.28 & 132 & 10 & 320 & 7.5 & 0.28 & 0.24 & 120 & 10 & 280 \\
\hline $\begin{array}{l}\text { Kinnow+Eucalypts+ } \\
\text { Wheat }\end{array}$ & 7.7 & 0.39 & 0.20 & 110 & 8 & 290 & 7.7 & 0.34 & 0.18 & 104 & 8 & 256 \\
\hline Control & 7.6 & 0.24 & 0.32 & 144 & 10 & 325 & 7.6 & 0.26 & 0.30 & 136 & 10 & 310 \\
\hline CD (5\%) & NS & 0.05 & 0.05 & 16 & NS & 24 & NS & 0.05 & 0.05 & 14 & NS & 20 \\
\hline
\end{tabular}

Table.2 Growth performance of eucalypts and kinnow under silvi -agri-horti system

\begin{tabular}{|c|c|c|c|c|c|c|c|c|c|}
\hline \multirow[b]{3}{*}{ Treatment } & \multicolumn{6}{|c|}{ Tree growth of Eucalyptus tereticornis } & \multirow{2}{*}{\multicolumn{3}{|c|}{ Annual growth increment }} \\
\hline & \multicolumn{3}{|c|}{ Initial } & \multicolumn{3}{|c|}{ At Harvest } & & & \\
\hline & $\begin{array}{c}\text { Height } \\
\text { (m) }\end{array}$ & $\begin{array}{c}\text { Basal } \\
\text { diameter } \\
(\mathbf{c m})\end{array}$ & $\begin{array}{r}\text { DBH } \\
(\mathbf{c m})\end{array}$ & $\begin{array}{c}\text { Height } \\
\text { (m) }\end{array}$ & $\begin{array}{c}\text { Basal } \\
\text { diameter } \\
(\mathrm{cm})\end{array}$ & $\begin{array}{l}\text { DBH } \\
(\mathbf{c m})\end{array}$ & $\begin{array}{l}\text { Height } \\
\left(m \mathbf{y r}^{-1}\right)\end{array}$ & $\begin{array}{c}\text { Basal } \\
\text { diameter } \\
\left(\mathrm{cm} \mathrm{yr}^{-1}\right)\end{array}$ & $\begin{array}{c}\text { DBH }(\mathbf{c m} \\
\left.\mathrm{yr}^{-1}\right)\end{array}$ \\
\hline $\begin{array}{l}\text { Eucalyptus } \\
\text { (Eucalyps + } \\
\text { Kinnow + Wheat) }\end{array}$ & 17.9 & 21.5 & 17.1 & 19.4 & 27.6 & 21.6 & 1.5 & 6.1 & 4.5 \\
\hline $\begin{array}{l}\text { Kinnow (Eucalyps } \\
+ \text { Kinnow + Wheat) }\end{array}$ & 2.70 & 6.94 & - & 2.81 & 7.44 & - & 0.11 & 0.5 & - \\
\hline $\begin{array}{l}\text { Kinnow (Kinnow+ } \\
\text { Wheat) }\end{array}$ & 2.80 & 7.60 & - & 3.09 & 8.62 & - & 0.29 & 1.02 & - \\
\hline CD $(p=0.05)$ & 3.521 & 6.112 & NS & 4.341 & 3.212 & NS & 0.21 & 0.45 & NS \\
\hline
\end{tabular}


Table.3 Effect agroforestry models on Plant height $(\mathrm{cm})$ as compared to sole cropping

\begin{tabular}{|c|c|c|c|c|c|}
\hline \multicolumn{2}{|r|}{ Treatment } & \multicolumn{4}{|c|}{ Plant height (cm) } \\
\hline & & 30 DAS & 60 DAS & 90 DAS & 120 DAS \\
\hline \multirow[t]{5}{*}{ Kinnow+Wheat } & $\mathrm{RDF}$ & 25.0 & 44.9 & 84.5 & 87.2 \\
\hline & $\mathrm{RDF}+10 \%$ additional dose of $\mathrm{N}$ & 27.4 & 47.8 & 88.6 & 91.2 \\
\hline & $\mathrm{RDF}+20 \%$ additional dose of $\mathrm{N}$ & 28.1 & 48.6 & 90.1 & 92.2 \\
\hline & $\mathrm{RDF}+30 \%$ additional dose of $\mathrm{N}$ & 28.6 & 49.3 & 90.8 & 92.6 \\
\hline & Mean & 27.3 & 47.7 & 88.5 & 90.8 \\
\hline \multirow{5}{*}{$\begin{array}{l}\text { Kinnow+ } \\
\text { Eucalypts+Wheat }\end{array}$} & $\mathrm{RDF}$ & 22.4 & 42.5 & 81.7 & 83.1 \\
\hline & $\mathrm{RDF}+10 \%$ additional dose of $\mathrm{N}$ & 24.2 & 45.3 & 84.8 & 86.2 \\
\hline & $\mathrm{RDF}+20 \%$ additional dose of $\mathrm{N}$ & 25.0 & 46.4 & 85.4 & 87.0 \\
\hline & $\mathrm{RDF}+30 \%$ additional dose of $\mathrm{N}$ & 25.3 & 47.0 & 86.2 & 88.1 \\
\hline & Mean & 24.2 & 45.3 & 84.5 & 86.1 \\
\hline Control & $\mathrm{RDF}$ & 29.9 & 52.2 & 91.3 & 93.3 \\
\hline \multirow{3}{*}{\multicolumn{2}{|c|}{$\begin{array}{l}\text { CD at 5\%: AFS } \\
\text { Fertilizer levels } \\
\text { AFS x FLS }\end{array}$}} & 1.2 & 1.5 & 2.4 & 2.1 \\
\hline & & 1.4 & 1.8 & 2.7 & 2.8 \\
\hline & & NS & NS & NS & NS \\
\hline
\end{tabular}

Table.4 Effect agroforestry models on yield attributing parameters of wheat as compared to sole cropping

\begin{tabular}{|c|c|c|c|c|c|}
\hline \multirow{2}{*}{\multicolumn{2}{|c|}{ Treatment }} & \multicolumn{4}{|c|}{ Yield attributes } \\
\hline & & \multirow{2}{*}{$\begin{array}{c}\text { Tillers/m² } \\
238.0 \\
\end{array}$} & \multirow{2}{*}{$\begin{array}{c}\begin{array}{c}\text { Ear } \\
\text { heads/ } \mathbf{m}^{2}\end{array} \\
235.3 \\
\end{array}$} & \multirow{2}{*}{$\begin{array}{c}\begin{array}{c}\text { Grains/ear } \\
\text { head }\end{array} \\
44.2 \\
\end{array}$} & \multirow{2}{*}{$\begin{array}{c}\begin{array}{c}\text { Test } \\
\text { weight }(\mathbf{g})\end{array} \\
43.8 \\
\end{array}$} \\
\hline Kinnow+Wheat & RDF & & & & \\
\hline & RDF $+10 \%$ additional dose of $\mathrm{N}$ & 266.0 & 261.1 & 48.0 & 46.7 \\
\hline & RDF $+20 \%$ additional dose of $N$ & 278.7 & 272.2 & 48.6 & 47.0 \\
\hline & RDF $+30 \%$ additional dose of $\mathrm{N}$ & 278.0 & 271.2 & 48.8 & 46.9 \\
\hline & Mean & 265.2 & 259.9 & 47.4 & 46.1 \\
\hline \multirow{5}{*}{$\begin{array}{l}\text { Kinnow+ } \\
\text { Eucalypts+Wheat }\end{array}$} & RDF & 228.0 & 223.0 & 40.7 & 39.8 \\
\hline & RDF $+10 \%$ additional dose of $\mathrm{N}$ & 244.0 & 239.0 & 43.6 & 43.0 \\
\hline & RDF $+20 \%$ additional dose of $N$ & 248.0 & 242.0 & 43.9 & 43.3 \\
\hline & RDF $+30 \%$ additional dose of $\mathrm{N}$ & 249.0 & 244.0 & 43.8 & 43.2 \\
\hline & Mean & 242.3 & 237.0 & 43.0 & 42.3 \\
\hline Control & RDF & 324.5 & 319.0 & 49.8 & 47.2 \\
\hline \multirow{3}{*}{\multicolumn{2}{|c|}{$\begin{array}{l}\text { CD at 5\%: AFS } \\
\text { Fertilizer levels } \\
\text { AFS } x \text { FLS }\end{array}$}} & 2.1 & 10.4 & 1.9 & 1.8 \\
\hline & & 2.8 & 14.7 & 2.7 & 2.6 \\
\hline & & NS & NS & NS & NS \\
\hline
\end{tabular}


Table.5 Effect agroforestry models on yield of wheat as compared to sole cropping

\begin{tabular}{|c|c|c|c|}
\hline \multirow{2}{*}{\multicolumn{2}{|c|}{ Treatment }} & \multicolumn{2}{|c|}{ Yield (t/ha) } \\
\hline & & Grain & Straw \\
\hline \multirow{5}{*}{ Kinnow+Wheat } & RDF & 2.50 & 3.88 \\
\hline & RDF $+10 \%$ additional dose of $N$ & 2.80 & 4.15 \\
\hline & RDF $+20 \%$ additional dose of $\mathrm{N}$ & 2.94 & 4.31 \\
\hline & RDF $+30 \%$ additional dose of $N$ & 2.90 & 4.25 \\
\hline & Mean & 2.79 & 4.15 \\
\hline \multirow{5}{*}{$\begin{array}{l}\text { Kinnow+ } \\
\text { Eucalypts+Wheat }\end{array}$} & RDF & 1.31 & 2.09 \\
\hline & RDF $+10 \%$ additional dose of $N$ & 1.47 & 2.29 \\
\hline & RDF $+20 \%$ additional dose of $\mathrm{N}$ & 1.54 & 2.33 \\
\hline & RDF $+30 \%$ additional dose of $N$ & 1.53 & 2.32 \\
\hline & Mean & 1.46 & 2.26 \\
\hline Control & RDF & 4.70 & 6.80 \\
\hline \multirow{3}{*}{\multicolumn{2}{|c|}{$\begin{array}{l}\text { CD at 5\%: AFS } \\
\text { Fertilizer levels } \\
\text { AFS x FLS }\end{array}$}} & 0.10 & 0.16 \\
\hline & & 0.15 & NS \\
\hline & & NS & NS \\
\hline
\end{tabular}

Fig.1 Effect agroforestry models on Plant population $\left(\right.$ per $\left.\mathrm{m}^{2}\right)$ as compared to sole cropping

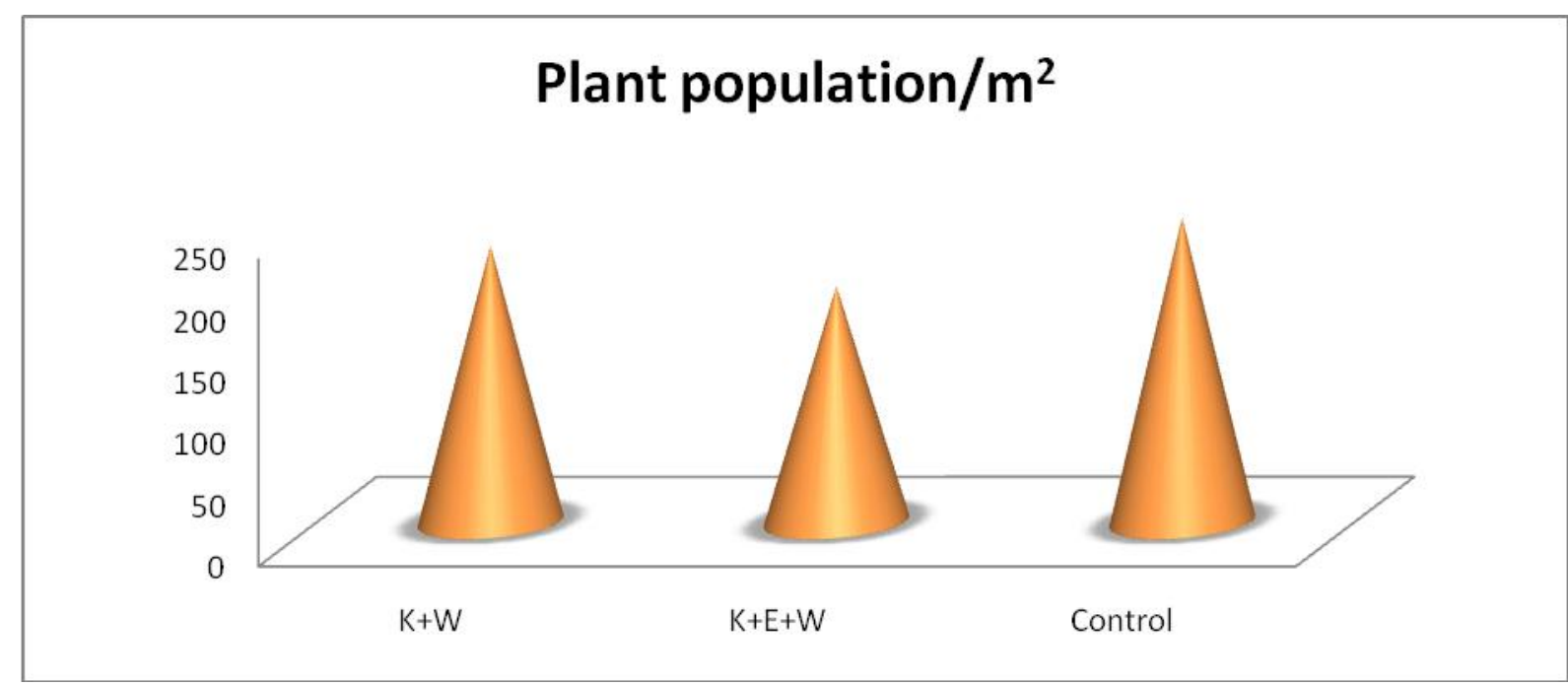

\section{Growth performance of perennials}

The overall growth pattern of eucalypts and kinnow under different agroforestry model generally followed increasing trend with the advancement of age. All the growth parameters after completing 5 years of agroforestry plantation are presented in (Table 2 ). The average initial tree height and basal diameter of Eucalyptus tereticornis under agri-silvi-horticultural system was $17.9 \mathrm{~m}$ and $17.1 \mathrm{~cm}$ respectively, while, the height and basal diameter of Kinnow was $2.70 \mathrm{~m}$ and $6.97 \mathrm{~cm}$ respectively in combination with Eucalypts whereas it showed $2.80 \mathrm{~m}$ height and $7.60 \mathrm{~cm}$ basal diameter in absence of trees. The annual increment in tree height and basal diameter was $1.5 \mathrm{~m}$ and $6.1 \mathrm{~cm}$ respectively. The annual increment in Kinnow was $0.11 \mathrm{~m}$ and $0.5 \mathrm{~cm}$ respectively with 
Eucalypts and while $0.29 \mathrm{~m}$ and $1.02 \mathrm{~cm}$ in absence of Eucalypts. The results shows a significant variation among the growth patterns of kinnow and Eucalypts which proves that when a crop is grown in association with trees, there is a competition for light, moisture, nutrients and a positive or negative interaction might be expected to develop between them. These results are also in close conformity with the findings of Kumar et al., (2013). Similar trends in growth of various trees under different agroforestry system have also been reported by Banerjee and Dhara (2011).

\section{Influence on growth parameters of wheat}

The significant variation in plant population was recorded among different agroforestry systems and control (Fig. 1). However, variation for plant population $/ \mathrm{m}^{2}$ was nonsignificant between agri-horti (kinnow+ wheat) and agri-silvi-horti (kinnow+ eucalypts + wheat) systems. The highest numbers of plants per square meter (248) were in control (non-agroforestry) followed by kinnow (225) based agroforestry system while the minimum population $\left(192 / \mathrm{m}^{2}\right)$ of wheat was observed in Kinnow + eucalypts based agroforestry system. Kiran et al., (2002) also revealed that plant population of wheat crop reduced upto 34 to 54 percent respectively, under Eucalyptus tereicornis and Dalbergia sissoo based agroforestry system. Similarly, plant height at 30, 60, 90 and 120 days after sowing (DAS) of wheat showed significant variation with varying levels of fertilizer under different agroforestry systems (Table 3). Significantly higher plant height was in agri-horti (kinnow + wheat) system as compared to agri-silvi-horti (kinnow + eucalypts + wheat) system. In agrihorti (kinnow + wheat) and agri-silvi-horti (kinnow + eucalypts + wheat) system, RDF + additional dose of $\mathrm{N}(10,20$ and 30\%) significantly increased the plant height over recommended dose of fertilizer at different time intervals of growth in wheat. Prasad et al., (2010) predicted a loss of 45 percent for various yield attributing characters of cowpea under Eucalyptus tereticornis based agroforestry system as compared to sole cropping in southern India. However, the differences between RDF $+10 \%$ additional dose of $\mathrm{N}, \mathrm{RDF}+20 \%$ additional dose of $\mathrm{N}$ and $\mathrm{RDF}+30 \%$ additional dose of $\mathrm{N}$ were non- significant.

\section{Yield and its attributes}

It was observed that the due to competition for moisture, light and nutrients among the annual crops, trees and fruit plants, the observed values for different yield attributing parameters were lesser than the sole crop with recommended doses of fertilizer. The number of tillers $\left(\mathrm{m}^{-2}\right)$ under both the agroforestry system $\left(265.2 \mathrm{~m}^{-2}, 242.3 \mathrm{~m}^{-2}\right)$ were much less as compared to the sole crop $\left(324.5 \mathrm{~m}^{-2}\right)$. Similar results were also obtained for other yield attributing parameters (Table 3 ).

Recommended dose of fertilizer + additional dose of $\mathrm{N}(10,20$ and $30 \%)$ significantly increased the yield attributing parameters over recommended dose of fertilizer in both agrihorti (kinnow + wheat) and agri-silvi-horti (kinnow + eucalypts + wheat) system.

However, the differences between RDF + $10 \%$ additional dose of N, RDF $+20 \%$ additional dose of $\mathrm{N}$ and $\mathrm{RDF}+30 \%$ additional dose of $\mathrm{N}$ were found to be nonsignificant. Similarly, Lott et al., (2009) recorded a poor growth maize crop under Grevillea robusta based agroforestry system in semi-arid Kenya. A net reduction of 25 percent in different parameters of maize was observed under the agroforestry system as compared to the sole crop due to $30-35 \%$ reduction in light intensity under agroforestry system as compared to the sole cropping. 
The significantly higher grain and straw yield of wheat (2.79 and $4.15 \mathrm{t} / \mathrm{ha}$ respectively,) was observed in case of agri-horti (kinnow + wheat) system as compared to agri-silvi-horti system (1.46 t/ha and $2.26 \mathrm{t} / \mathrm{ha}$ respectively) (Table 4). An increase of 83.6 and 91.0 per cent in straw and grain yield, respectively of wheat was recorded under kinnow plus wheat system as compared to kinnow plus eucalypts based agroforestry system. However, the grain yield of wheat under agroforestry was less as compared to sole crop with recommended doses of fertilizer. However, recommended dose of fertilizer + additional dose of $\mathrm{N}(10,20$ and 30\%) significantly increased the grain yield over recommended dose of fertilizer under both the agroforestry systems while varying fertilizer levels did not influence straw yield of wheat under both the agroforestry systems (Table 5). The results revealed that an average grain yield reduction under Kinnow + Eucalypts and Kinnow alone was 68.9 and 40 per cent, respectively as compared to sole crop may due to competition of light among the annuals and perennials. Similarly, Rana et al., (2007) and Verma and Rana (2014) also witnessed a yield reduction in paddy and wheat (14.9 and 29.7 percent respectively) under agroforestry system as compared to the sole cropping.

\section{References}

Aguiar, A.C.F., Bicudo, S.J., Sobrinho, J.R.S.C., Martins, A.L.S., Coelho, K.P., Moura, E.G., 2010. Nutrient recycling and physical indicators of an alley cropping system in a sandy loam soil in the pre-Amazon region of Brazil. Nutrient Cycling in Agroecosystems, 86: 189-198.

Anderson SH, Udawatta RP, Seobi T, Garrett HE. 2009. Soil water content and infiltration in agroforestry buffer strips. Agroforestry System. 75:5-16.

Antonio, C., Gama-Rodrigues., 2011. Soil organic matter, nutrient cycling and biological dinitrogen-fixation in agroforestry systems. Agroforestry Systems. 81: 191-193.

Banerjee. H., and Dhara P.K., 2011. Evaluation of different agri-horti-silvicultural models for rainfed uplands in west Bengal. Progress in Agricultural sciences.s 11(1): 143-148.

Belsky AJ, Amundson RG, Duxbury JM, Riha SJ, Ali AR, Mwonga SM. 1989. The effects of trees on their physical, chemical, and biological environments in a semi-arid savanna in Kenya. Applied Ecology 26:1005-1024.

Dalal, V., Bhardwaj, K.K, Kathwal, Rajesh and Kaushik, N. 2016. An agri-silvihorticultural system to optimize production, quality and cash returns in Indo-Gangatic alluvial plains of Haryana. Ind. J. Eco. 43: 281-287.

Das, D.K., Chaturvedi, O.P., 2005. Structure and function of Populus deltoides agroforestry system in eastern India: 1 Dry matter dynamics. Agroforestry Systems. 65: 215-221.

Dhyani, S.K., Handa, A.K. and Uma, 2013. Area under agro forestry in India: An assessment for present status and future perspective. Indian Journal of Agroforestry, 15(1): 1-11.

Fadl KEM, Sheikh SEE. 2010. Effect of Acacia senegal on growth and yield of groundnut, sesame and roselle in an agroforestry system in North Kordofan state, Sudan. Agroforestry System 78:243-252.

Fang, S., Huayong, L., Baodong, X., 2008. Decomposition and nutrient release of four potential mulching materials for poplar plantations on upland sites. Agroforestry Systems. 74: 27-35.

FAO. 2004. Assessing carbon stocks and modelling: Win-Win scenarios of carbon sequestration through land-usechanges. Rome: FAO; p. 156

FAO. 2004. Assessing carbon stocks and modelling: Win-Win scenarios of carbon sequestration through land-use changes. Rome: FAO; p. 156

FAO. 2013. Advancing agroforestry on the 
policy agenda. Agroforestry Working Paper No. 1, Rome: FAO.

Fukushima T, Morimoto Y, Maundu P, Kahindi B, Fondo J. 2010. Local preference of indigenous fruit trees in Coast Province, Kenya. African Env Sci Tech. 4:872-885.

Gajja BL, Bhati TK, Harsh LN, Khan MS. 1999. Comparative economics of silvipasture, horticulture and annual crops on marginal lands of arid zone of Rajasthan. Annals Arid Zone. 38:173180.

Gathumbi SM, Ndufa JK, Giller KE, Cadisch G. 2002. Do species mixtures increase above- and below-ground resource capture in woody and herbaceous tropical legumes? Agron J. 94:518-526.

Gupta, M.K., Sharma, S.D., 2009. Effect of tree plantation on soil properties, profile morphology and productivity index: poplar in Yamunanagar district of Hariyana. Annals of Forestry. 17: 43-70.

Harsh LN, Tewari JC, Burman U, Sharma SK. 1992. Agroforestry in arid regions. Indian Farming.42:32-37.

Hymavathi, H.N., Kandhya, A.K., Patil, L.P., 2010. Beneficial effects of multiple plantations in agroforestry systems. Indian Forester. 4: 465-475.

Ilany T, Ashton MS, Montagnini F, Martinez C. 2010. Using agroforestry to improve soil fertility: effects of intercropping on Ilex paraguariensis (yerba mate) plantations with Araucaria angustifolia. Agroforestry System 80:399-409.

Jackson ML. 1973. Soil chemical analysis. Prentice Hall of India, Pvt. Ltd, New Delhi. pp: 498.

Jianbo L. 2006. Energy balance and economic benefits of two agroforestry systems in northern and southern China. Agriculture Ecosystem and Environment 116:255262.

Jose, S., 2009. Agroforestry for ecosystem services and environmental benefits: an overview. Agroforestry Systems. 76: 1-10.

Kiran R, Agnihotri AK and Saini BC 2002. Wheat yield as influenced by net radiation availability below Eucalyptus tereticornis and Dalbergia sissoo canopies. Indian Journal of Agricultural Research. 36: 6870.

Kumar, B.M., Singh, A.K. and Dhyani, S.K., 2012. South Asian agro forestry: traditions, transformations and prospects. In: Agro-forestry- The Future of Global Land Use (Eds. Nair, P.K.R. and Garrity, D.). Advances in Agro forestry 9. Springer, Dordrecht.

Leakey RRB, Simons AJ. 1998. The domestication and commercialization of indigenous trees in agroforestry for the alleviation of poverty. Agroforestry System 38:165-176.

Lott JE, Ong CK and Black CR 2009. Understorey microclimate and crop performance in a Grevillea robusta-based agroforestry system in semi-arid Kenya. Agricultural and Forest Meteorology 149: 1140-1151.

Murthy IK, Gupta M, Tomar S, Munsi M, Tiwari R, Hegde GT, Ravindranath NH. 2013. Carbon sequestration potential of agroforestry systems in India. $J$ Earth $S c i$ Climate Change. 4:1-9.

Muthuri, C.W., Ong, C.K., Black, C.R., Ngumi, V.W., Mati, B.M., 2005. Tree and crop productivity in Grevillea, Alnus and Paulownia-based agroforestry systems in semi-arid Kenya. Forest Ecology and Management. 212: 23-39.

Nair PKR, Buresh RJ, Mugendi DN, Latt CR. 1999. Nutrient cycling in tropical agroforestry systems: myths and science. In: Buch LE, Lassoie JP, Fernandes ECM, editors. Agroforestry in sustainable agricultural systems. Boca Raton, FL: CRC Press; p. 1-31.

Ndayambaje J, Mohren G. 2011. Fuelwood demand and supply in Rwanda and the role of agroforestry. Agroforestry system 83:303-311.

Olsen SR, Cole CV, Watanabe FS and Dean LA. 1954. Estimation of available phosphorus in soils by extraction with sodium bi-carbonate. United States Department of Agriculture Circular. pp: 939. 
Pandey DN. 2007. Multifunctional agroforestry systems in India. Current Sci. 92:455463.

Paoli, G.D., Curran, L.M., Slik, J.W.F., 2008. Soil nutrients affect spatial patterns of aboveground biomass and emergent tree density in southwestern Borneo. Oecologia. 155: 287-299.

Pinho RC, Alfaia SS, Miller RP. 2011. Islands of fertility: soil improvement under indigenous home gardens in the savannas of Roraima, Brazil. Agrofor Syst. 81:235247.

Prasad JVNS, Korwar GR, Rao KV, Mandal UK, Rao CAR, Rao GR, Ramakrishna YS, Venkateswarlu B, Rao SN, Kulkarni HD and Rao MR 2010. Tree row spacing affected agronomic and economic performance of Eucalyptus-based agroforestry in Andhra Pradesh, Southern India. Agroforestry System. 78: 253-267.

Rana BS, Saxena AK and Parihar AKS 2007. Status and scope of agroforestry development in eastern part of Uttar Pradesh. In: Agroforestry: System and Practices. (Sunil Puri and Pankaj Panwar, eds) New India Publishing Agency, New Delhi. Pp 191-211.

Singh G. 2010. Rainfall dependent competition effected productivity of $\mathrm{V}$. radiata in Hardwickia binata agroforestry in Indian Desert. Indian Forester. 136:301-315.

Stahl L, Nyberg G, Hogberg P, Buresh RJ. 2002. Effects of planted tree fallows on soil nitrogen dynamics, above-ground and root biomass, N2-fixation and subsequent maize crop productivity in Kenya. Plant
Soil. 243:103-117.

Subbaih BV and Asija GL.1956. A rapid procedure to for the estimation of the available nitrogen in soils. Current Science 25: 259-260.

Udawatta RP, Jose S. 2012. Agroforestry strategies to sequester carbon in temperate North America. Agroforestry System. 86:225-242.

Vallejo VE, Arbeli Z, Teran W, Lorenz N, Dick RP, Roldan F. 2012. Effect of land management and Prosopis juliflora (Sw.) DC trees on soil microbial community and enzymatic activities in intensive silvopastoral systems of Colombia. Agri Ecosyst Environ. 150:139-148.

Verma SK and Rana BS 2014. Effect of light intensity on paddy and wheat grain yield under Eucalyptus tereticornis SM. Based agri-silvicultural system. Indian Forester 140: 23-28.

Walkely A and Black IA. 1934. An examination method for determining soil organic matter and a proposed modification of the chromic acid titration method. Soil science. 37: 29-37.

Yadav RS, Yadav BL, Chhipa BR. 2008. Litter dynamics and soil properties under different tree species in a semi-arid region of Rajasthan, India. Agroforestry System 73:1-12.

Yadav, R.S., Yadav, B.L., Chhipa, B.R., 2008. Litter dynamics and soil properties under different tree species in a semi-arid region of Rajasthan, India. Agroforestry Systems. 73: $1-12$.

\section{How to cite this article:}

Vishal Johar, R.S. Dhillon, K.S. Bangarwa and Bhardwaj, K.K. 2017. Effect of Eucalyptus Based Agri-Silvi-Horticultural System on Growth and Yield of Wheat in North-Western Region of Haryana, India. Int.J.Curr.Microbiol.App.Sci. 6(11): 2702-2711. doi: https://doi.org/10.20546/ijcmas.2017.611.318 